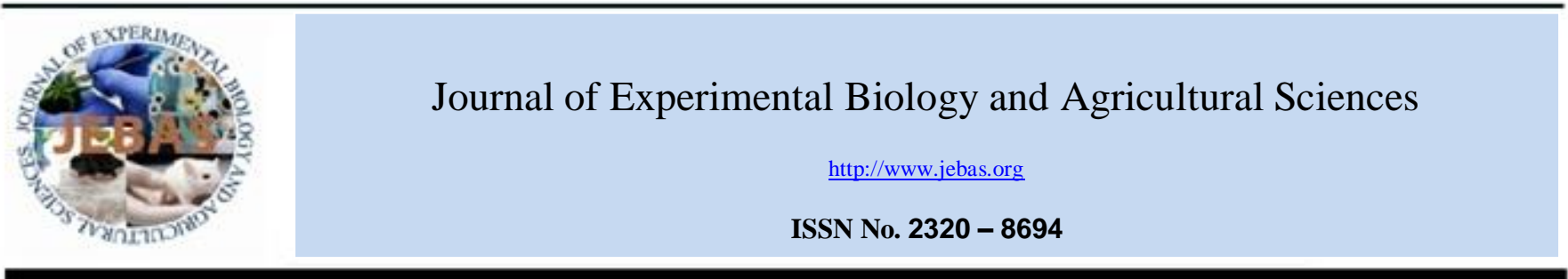

\title{
GROWTH ANALYSIS OF AREA, PRODUCTION AND PRODUCTIVITY OF WHEAT CROP IN HARYANA AND INDIA
}

\author{
Nisha $^{1 *}$, Mohit Nain ${ }^{2}$, D.R. Aneja ${ }^{3}$ \\ Department of Mathematics and Statistics, CCS Haryana Agricultural University, Hisar-125004 (Haryana), India
}

Received - February 09, 2019; Revision - April 21, 2019; Accepted - May 21, 2019

Available Online - June 10, 2019

DOI: http://dx.doi.org/10.18006/2019.7(3).266.272

\section{KEYWORDS \\ Wheat \\ Instability \\ Coefficient of variation \\ Linear growth rate \\ Compound growth rate \\ Variability}

\begin{abstract}
The study intends to scrutinize the performance of wheat production in Haryana and India during the period 1966-67 to 2012-13; this time period were divided in five sub periods i.e. P-I (1966-67 to 1975 76), P-II (1976-77 to 1985-86), P-III (1986-87 to 1995-96), P-IV (1996-97 to 2005-06) and P-V (200607 to 2012-13). The study is exclusively based on secondary data. The Result of study revealed positive trends in area, production and yield of wheat for both Haryana and India. Similar results were obtained on the triennium basis. The contribution of area and yield in the production of wheat are comparable for both Haryana and India. All the selected three aspects (i.e. area, production and yield) have shown positive growth rates in Haryana while in case of India, positive growth rates were observed for only area and production except in Period- IV (1996-97 to 2005-06). Trend of yield in India was similar to that of Haryana. Similar results are observed for coefficient of variation and stability indices in production and yield of wheat in Haryana as well as India.
\end{abstract}

* Corresponding author

E-mail: nisha.stats22@gmail.com (Nisha)

Peer review under responsibility of Journal of Experimental Biology and Agricultural Sciences.

Production and Hosting by Horizon Publisher India [HPI] (http://www.horizonpublisherindia.in/).

All rights reserved.
All the articles published by Journal of Experimental Biology and Agricultural Sciences are licensed under a Creative Commons Attribution-NonCommercial 4.0 International License Based on a work at www.jebas.org.

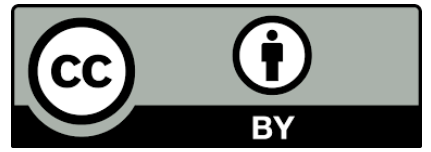




\section{Introduction}

Wheat (Triticum aestivum) is one of the most important crop in the world and gives a major contribution in food grain production. It is the staple food for most of world population and an excellent source of carbohydrates and energy without fat. Indian economy in general and the economy of Haryana in particular, witnessed a distinctive change since mid-sixties with the development of High Yielding Varieties (HYVs) of wheat. Abraham \& Raheja (1967) found that the growth in productivity of rice and wheat during 1951-52 to 1964-65 was mainly due to increase in fertilizers for both the crops in India. Singh \& Supriya (2017) studied the trend in area, production and yield of wheat crop in Uttar Pradesh, India for the period 1971-2010 and found that among the three aspects (area, production and productivity), productivity has shown higher growth rates due to increased trend in growth rates of area and productivity and also for estimation of these three aspects cubic model was found to be the best for wheat crop in India. Kumar et al. (2017) analyzed growth rates in area, production and productivity of major cereal crops in Sikkim and observed a drastic reduction in the production and area of cultivation of major cereal crops in Sikkim. Keeping this in view, the present paper is an attempt to examine the growth and instability in area, production and productivity of wheat crop in Haryana and India. Thus for examining the growth rates both linear as well as exponential functions are fitted. In order to determine the variability and Instability among the three aspects i.e. area, production and productivity coefficient of determination and Cuddy-Della Valle Index are computed.

\section{Materials and Methods}

The study was entirely based on secondary data. The time series data related to area, production and yield of wheat in Haryana and India for the period of 47 years i.e. 1966-67 to 2012-13 was obtained from various issues of Statistical Abstract of Haryana, Statistical Abstract of India (http://esaharyana.gov.in/enus/State-Statistical-Abstract-of-Haryana) and Agricultural Situation in India (https://www.indiaagristat.com/agriculturedata/2/agricultural-area- land-use/152/stats.aspx). The entire study period (1966-67 to 2012-13) was divided into five sub-periods in order to have a period-wise examination of growth and variability patterns of area, production and productivity of wheat and the sub periods were as follows: Period I, 1966-67to 1975-76; Period II, 197677 to 1985-86; Period III, 1986-87 to 1995-96; Period IV, 1996-97 to 2005-06; Period V, 2006-07 to 2012-13. By taking area/production/yield as dependent variable $\left(\mathrm{Y}_{\mathrm{t}}\right)$ and year number $(\mathrm{t})$ as independent variable linear as well as exponential functions were fitted for computing various growth rates. The Coefficient of determination $\left(\mathrm{R}^{2}\right)$ was also computed to scrutinize whether or not the linear and exponential functions adequately fit the available data.
To study the contribution of area, yield and the interaction of area and yield towards increasing the wheat production in state as well as country, a decomposition analysis was performed as given below. Several workers used this decomposition analysis and studied growth performance of crops (Bastine \& Palanisami, 1994; Bhatnagar \& Nandal, 1994; Gupta \& Saraswat, 1997; Singh \& Ranjan, 1998; Siju \& Kombairaju, 2001).

$\Delta \mathrm{Q}=\mathrm{A}_{0} \Delta \mathrm{Y}+\mathrm{Y}_{0} \Delta \mathrm{Q}+\Delta \mathrm{A} \Delta \mathrm{Y}$

The first term on the right hand side can be considered as the yield effect, the second term as the area effect and third as the interaction effect. Thus, the total change in production can be decomposed into three effects, viz.; yield effect, area effect and the interaction effect due to the change in yield and area.

To measure the magnitude of Variability in area, production and productivity, the coefficient of variation was computed using the formula:

$$
\text { Coefficient of Variation (C.V.) }=\frac{S . D}{\bar{X}} \times 100
$$

Where, S.D = Standard Deviation of area/production/yield

$$
\bar{X}=\text { Mean value of area/production/yield of the crop }
$$

under consideration

$$
\text { Cuddy-Della Valle Index }(\mathrm{CDI})=\mathrm{C} \cdot \mathrm{V} \cdot \sqrt{1-R^{2}}
$$

Where,

C.V. = Coefficient of Variation

$\mathrm{R}^{2}=$ ESS/TSS i.e. ratio of explained variation to total variation.

ESS $=$ Variation explained by explanatory variable.

TSS $=$ Total Variation

\section{Results and Discussion}

Changes in area, production and yield of wheat in Haryana and India during study period are shown in Table 1 and Table 2 respectively.

For wheat crop, the area was increased from 743 to 2497 thousand hectares i.e. 1754 thousand hectares more area came under Haryana during the last 47 years ( Table 1) whereas for India the area under wheat crop increased by 17.16 million hectares i.e. from 12.84 to 30.00 million hectares in the same period (Table 2). It depicts that rise in area of wheat was 236.07 and 133.65 per cent for Haryana and India respectively. So increase in area for wheat in Haryana was much higher as compared to that in India. In Haryana, the production of wheat increased by 949.8 per cent whereas the corresponding increase was 720.48 per cent at the country level during this period. So, the rise in production of wheat in Haryana was higher than that for India. The average yield in Haryana shot up from $1425 \mathrm{~kg} / \mathrm{ha}$ to $4452 \mathrm{~kg} / \mathrm{ha}$, giving a net increase of $3027 \mathrm{~kg} / \mathrm{ha}$ whereas for India it has increased from $887 \mathrm{~kg} / \mathrm{ha}$ to $3117 \mathrm{~kg} / \mathrm{ha}$ i.e. a net increase of $2230 \mathrm{~kg} / \mathrm{ha}$ (Table 1). 
Table 1 Changes in area, production and yield of wheat in Haryana from 1966-67 to 2012-13 on yearly and triennium basis

\begin{tabular}{|c|ccccc|cccc|}
\hline \multirow{2}{*}{ Variable } & \multicolumn{6}{|c|}{ Yearly Basis } & \multicolumn{4}{c|}{ Triennium Basis } \\
\cline { 2 - 9 } & $\begin{array}{c}\text { Base year } \\
(1966-67)\end{array}$ & $\begin{array}{c}\text { Current year } \\
(2012-13)\end{array}$ & $\begin{array}{c}\text { Net } \\
\text { Change }\end{array}$ & $\begin{array}{c}\text { Per cent } \\
\text { Change }\end{array}$ & $\begin{array}{c}\text { Base Triennium } \\
(1966-67 \text { to } \\
1968-69)\end{array}$ & $\begin{array}{c}\text { Current Triennium } \\
(2010-11 \text { to } \\
2012-13)\end{array}$ & $\begin{array}{c}\text { Net } \\
\text { Change }\end{array}$ & $\begin{array}{c}\text { per cent } \\
\text { Change }\end{array}$ \\
\hline $\begin{array}{c}\text { Area } \\
\text { ('000 ha) }\end{array}$ & 743.00 & 2497.00 & 1754.00 & 236.10 & 827.33 & 2511.33 & 1684.00 & 203.55 \\
\hline $\begin{array}{c}\text { Production } \\
\text { ('000 tonnes) }\end{array}$ & 1059.00 & 11117.00 & 10058.00 & 949.80 & 1342.00 & 11811.00 & 10469.00 & 780.10 \\
\hline $\begin{array}{c}\text { Yield } \\
\text { (kg/ha) }\end{array}$ & 1425.00 & 4452.00 & 3027.00 & 212.40 & 1612.67 & 4702.00 & 3089.33 & 191.57 \\
\hline
\end{tabular}

Table 2 Changes in area, production and yield of wheat in India from 1966-67 to 2012-13 on yearly and triennium basis

\begin{tabular}{|c|cc|ccc|ccc|}
\hline Variable & \multicolumn{4}{c}{ Yearly Basis } & \multicolumn{4}{c|}{ Triennium Basis } \\
\hline $\begin{array}{c}\text { Base year } \\
(1966-67)\end{array}$ & $\begin{array}{c}\text { Current } \\
\text { year } \\
(2012-13)\end{array}$ & Net Change & $\begin{array}{c}\text { per cent } \\
\text { Change }\end{array}$ & $\begin{array}{c}\text { Base year } \\
(1966-67 \text { to } \\
1968-69)\end{array}$ & $\begin{array}{c}\text { Current year } \\
(2010-11 \\
\text { to 2012-13) }\end{array}$ & $\begin{array}{c}\text { Net } \\
\text { Change }\end{array}$ & $\begin{array}{c}\text { per cent } \\
\text { Change }\end{array}$ \\
\hline $\begin{array}{c}\text { Area } \\
\text { (m ha) }\end{array}$ & 12.84 & 30.00 & 17.16 & 133.65 & 14.60 & 29.64 & 15.04 & 103.01 \\
\hline $\begin{array}{c}\text { Production } \\
\text { (m tonnes) }\end{array}$ & 11.39 & 93.50 & 82.11 & 720.48 & 15.52 & 91.75 & 76.23 & 491.17 \\
\hline Yield (kg/ha) & 887.00 & 3117.00 & 2230.00 & 251.41 & 1053.00 & 3094.00 & 2041.00 & 193.83 \\
\hline
\end{tabular}

On triennium basis, average area under wheat crop in Haryana inflated from 827.33 thousand hectares (1966-67 to 1968-69) to 2511.33 thousand hectares (2010-11 to 2012-13) i.e. giving an increase of 203.55 per cent whereas at country level, it increased from 14.60 million hectares to 29.64 million hectares with a net change of 15.04 million hectares or 103 per cent (Table 1 and Table 2). The percentage change in production of wheat was at the tune of 780.0 per cent in Haryana and it increased by 491.17 per cent in India during this period. Increase in production of wheat crop was observed more in Haryana than in India. Yield shot up from $1612.67 \mathrm{~kg} / \mathrm{ha}$ to $4702.0 \mathrm{~kg} / \mathrm{ha}$ giving a net change of $3089.33 \mathrm{~kg} /$ hectare in Haryana (191.57 per cent) whereas at country level, it increased from $1053.0 \mathrm{~kg} /$ hectare to 3094.0 $\mathrm{kg} / \mathrm{ha}$ showing a net change of $2041.0 \mathrm{~kg} /$ hectare (193.83 per cent). Contribution of different factors in the production of wheat in Haryana and India are shown in Table 3.

In Haryana during Period-I, the production of wheat was increased by 30.1 and 50.3 per cent due to yield and area respectively whereas their joint effect has 19.6 per cent contribution. At the country level, the yield, area and their interaction have contributed 38.5, 38.7 and 22.8 percent respectively, towards its production (Table 3). The contribution of yield was more prominent in Haryana and the contribution of area and yield were at par in India for this period towards the production of yield. Overall pattern of influence of these three components was same for both Haryana and India in the decade from 1996-97 to 2005-06. During the Period-II, the production was increased by 57 per cent, 28 per cent and 15 per cent due to yield, area and their interaction respectively in Haryana. At the
Table 3 Contribution of different factors in the production of wheat in Haryana and India

\begin{tabular}{|c|c|c|c|}
\hline \multirow{2}{*}{ Period } & \multirow{2}{*}{ Effect } & \multicolumn{2}{|c|}{ Wheat } \\
\hline & & Haryana (\%) & India $(\%)$ \\
\hline \multirow{3}{*}{ I } & Area & 50.30 & 38.70 \\
\hline & Yield & 30.10 & 38.50 \\
\hline & Yield $\times$ Area & 19.60 & 22.80 \\
\hline \multirow{3}{*}{ II } & Area & 28.00 & 16.00 \\
\hline & Yield & 57.00 & 76.50 \\
\hline & Yield $\times$ Area & 15.00 & 7.50 \\
\hline \multirow{3}{*}{ III } & Area & 24.00 & 20.20 \\
\hline & Yield & 68.60 & 73.80 \\
\hline & Yield $\times$ Area & 7.40 & 6.00 \\
\hline \multirow{3}{*}{ IV } & Area & 108.00 & 25.00 \\
\hline & Yield & -7.00 & 26.50 \\
\hline & Yield $\times$ Area & -1.00 & 48.50 \\
\hline \multirow{3}{*}{ V } & Area & 48.20 & 30.70 \\
\hline & Yield & 49.20 & 64.70 \\
\hline & Yield $\times$ Area & 2.60 & 4.60 \\
\hline \multirow{3}{*}{ Overall } & Area & 24.90 & 18.50 \\
\hline & Yield & 22.40 & 34.90 \\
\hline & Yield $\times$ Area & 52.70 & 46.60 \\
\hline
\end{tabular}


national level, the contribution towards production by these components was 76.5 per cent, 16 per cent and 7.5 per cent respectively. So the pattern of influence of these factors was similar both for Haryana as well as India during this period.

In Period-III, the overall production of wheat in Haryana, the yield contributed 68.6 per cent, area has 24 per cent contribution and the joint effect of area and yield was having 7.4 per cent contribution. Similar results were obtained by Laitonjam et al. (2018) in the production of pulses in India during the study period i.e. 1980-2014. At the country level the rise in production of wheat was 73.8 per cent due to yield, 20.2 per cent due to area and 6.0 per cent from their joint effect. Hence for both Haryana and India, yield played a significant role to increase its production and the pattern of contribution was the similar both for Haryana and India. During Period-IV, while yield and its interaction with area has small but negative effects to the extent of 7 and 1 per cent respectively, only area was the factor responsible for the production of wheat crop in Haryana. At the country level, 26.5, 25 and 48.5 per cent contributions were observed due to yield, area and their interaction, respectively, towards the production of wheat. In Haryana during Period- $\mathrm{V}$, the contribution of yield and area in the production of wheat were 49.2 and 48.2 per cent respectively while only 2.6 per cent contribution was observed from their interaction. Similarly, for India, the yield and area effects were 64.7 and 30.7 per cent respectively and 4.6 per cent due to their interaction. Hence yield was the major contributor in the production of wheat in Haryana as well as in India during this period.

For the overall period under study, the percentage contribution of yield, area and their interaction towards the overall production in Haryana were $22.4,24.9$ and 52.7 per cent respectively whereas at the country level the contributions of these three factors were 34.9, 18.5 and 46.6 per cent respectively. Among the two factors of production, the contribution of area was more in Haryana whereas the yield contributed more at the national level for the overall period. The contributions of the joint effects of area and yield was at par both for increase of the production of wheat crop in Haryana as well in India during this period.

Under wheat crop 5.33 compound growth rates was observed in Haryana which was more than India (4.18) for Period-I, while the compound growth rates for production and yield i.e. 7.87 and 3.54, were more in case of India (Table 4). The annual increase in area,

Table 4 Growth rates of area, production and yield of wheat crop in Haryana and India

\begin{tabular}{|c|c|c|c|c|c|}
\hline \multirow[b]{2}{*}{ Period } & \multirow[b]{2}{*}{ Variable } & \multicolumn{2}{|c|}{ Haryana } & \multicolumn{2}{|c|}{ India } \\
\hline & & $\begin{array}{c}\text { Linear } \\
\text { growth rate (b) }\end{array}$ & $\begin{array}{c}\text { Compound } \\
\text { growth rate }(\%)\end{array}$ & $\begin{array}{c}\text { Linear } \\
\text { growth rate (b) }\end{array}$ & $\begin{array}{c}\text { Compound } \\
\text { growth rate }(\%)\end{array}$ \\
\hline \multirow[t]{3}{*}{ I } & Area & $51.44^{* *}$ & $5.33^{* *}$ & $0.68^{* *}$ & $4.18^{* *}$ \\
\hline & Production & $107.00^{* *}$ & $6.64^{* *}$ & $1.47^{* *}$ & $7.87^{* *}$ \\
\hline & Yield & 20.28 & 1.24 & $40.18^{* *}$ & $3.54^{* *}$ \\
\hline \multirow[t]{3}{*}{ II } & Area & $48.00^{* *}$ & $3.15^{* *}$ & $0.29^{* *}$ & $1.29^{* *}$ \\
\hline & Production & $257.02^{* *}$ & $7.03^{* *}$ & $2.01^{* *}$ & $5.48^{* *}$ \\
\hline & Yield & $90.85^{* *}$ & $3.76^{* *}$ & $68.10^{* *}$ & $4.13^{* *}$ \\
\hline \multirow[t]{3}{*}{ III } & Area & $27.81^{* *}$ & $1.49^{* *}$ & $0.26^{* *}$ & $1.08^{* *}$ \\
\hline & Production & $277.46^{* *}$ & $4.61^{* *}$ & 2.11 & 3.98 \\
\hline & Yield & $98.87^{* *}$ & $3.07^{* *}$ & $63.11^{* *}$ & $2.87^{* *}$ \\
\hline \multirow[t]{3}{*}{ IV } & Area & $29.28^{* *}$ & $1.36^{* *}$ & -0.05 & -0.18 \\
\hline & Production & 127.03 & 1.55 & -0.05 & -0.06 \\
\hline & Yield & 6.84 & 0.19 & 2.69 & 0.11 \\
\hline \multirow[t]{3}{*}{$\mathrm{V}$} & Area & $19.14^{* *}$ & $0.78^{* *}$ & $0.39^{* *}$ & $1.37^{* * *}$ \\
\hline & Production & $318.14^{*}$ & $2.92^{*}$ & $3.28^{* *}$ & $3.94^{* * *}$ \\
\hline & Yield & 94.22 & 2.11 & $73.50^{* *}$ & $2.53^{* *}$ \\
\hline \multirow[t]{3}{*}{ Overall } & Area & $36.70^{* *}$ & $2.25^{* *}$ & $0.28^{* *}$ & $1.25^{* *}$ \\
\hline & Production & $237.12^{* * *}$ & $4.77^{* *}$ & $1.62^{* *}$ & $3.68^{* *}$ \\
\hline & Yield & $70.44^{* *}$ & $2.46^{* *}$ & $45.96^{* *}$ & $2.40^{* *}$ \\
\hline
\end{tabular}

"significant at $5 \% \quad{ }^{* *}$ significant at $1 \%$ 
production and productivity for Haryana were 51.44 thousand ha, 107.00 thousand tonnes and $20.28 \mathrm{~kg} / \mathrm{ha}$, as compared to $0.68 \mathrm{~m}$ ha, 1.47 million tonnes and $40.18 \mathrm{~kg} / \mathrm{ha}$ at the country level, respectively. Similar results were obtained by Bhatnagar \& Sexena (2000) for wheat crop in Haryana. During Period-II the values of trend coefficients were 3.15, 7.03 and 3.76 per cent for area, production and yield of wheat respectively, giving an increase of 48 thousand hectares, 257.02 thousand tonnes and $90.85 \mathrm{~kg} / \mathrm{ha}$ respectively every year in Haryana. Area, production and yield were increased with highly significant growth rates of $1.29,5.48$ and 4.13 per cent respectively and their annual increase were recorded to be 0.29 million hectares, 2.01 million tonnes and $68.10 \mathrm{~kg} / \mathrm{ha}$ respectively for India. Thus the rate of increase in the yield of wheat in India $(40.18 \mathrm{~kg} / \mathrm{ha})$ was faster than that of Haryana $(86.10 \mathrm{~kg} / \mathrm{ha}$ ) during Period-II.

For Period-III, the area of wheat in Haryana escalated with highly significant growth rates i.e. 1.49 per cent (showing that 27.81 thousand hectares more area came under wheat crop every year). There was appreciable increase in its production with highly significant growth rate of 4.61 per cent giving an increase of 277.46 thousand tonnes per annum. Comparable results were obtained for wheat crop in Haryana by Bhatnagar \& Nandal (1994) and in Chattisgarh district of Madhya Pradesh by Ali \& Singh (1995) for the same crop. Yield has also increased with highly significant rate of 3.07 per cent (an annual increase of $98.87 \mathrm{~kg} / \mathrm{ha}$ ). At the country level, the production of wheat in this period has a growth rate of 3.98 per cent (i.e. 2.11 million tonnes more production every year). Area and yield has also highly significant growth rates of 1.08 and 2.87 per cent respectively affecting annual increase of 0.26 million hectares in area and $63.11 \mathrm{~kg} / \mathrm{ha}$ yield of wheat in the country during this period.

In Haryana wheat crop have shown an appreciable increase in area with significant rate of 1.36 percent during Period-IV while this improvement were 1.55 and 0.19 percent for its production and yield respectively. At the national level, area and production of wheat crop declined with growth rate of 0.18 and 0.06 per cent in India though the yield has increased with 0.11 per cent rate of growth (an annual increase of $2.69 \mathrm{~kg} / \mathrm{ha}$ ). During Period-V the area under the wheat crop has grown with significant rate of 0.78 per cent, production increased significantly with 2.92 per cent growth rate and yield increased with rate of 2.11 per cent in Haryana. Similar results were obtained by Netam \& Sahu (2017) for the area and productivity of rice crop in Chhattisgarh during the period of study 2000-01 to 2011-12.

The growth rate for area, production and productivity during this period were $1.37,3.94$ and 2.53 per cent respectively giving an annual increase of 0.39 million hectares, 3.28 million tonnes and $73.5 \mathrm{~kg} / \mathrm{ha}$ respectively in India.
For the entire period, the trend in area under wheat crop revealed a highly significant growth of 2.25 per cent and for its production and productivity it was 4.77 and 2.46 per cent respectively in Haryana (Table 5). Similar results were retrieved by Gautam \& Sisodia (2018) for the area, production and yield of wheat crop in Uttar Pradesh. For India, the trend coefficient for wheat crop have shown positive growth rates of $1.25,3.68$ and 2.40 per cent for area, production and yield respectively during this period (Table 5). Similar results were obtained by Ganjeer et al. (2017) for the area, production and productivity of wheat crop in different districts of Northern Hills of Chhattisgarh for the period 1979-80 to 2012-13 and Abid et al. (2014) for sugarcane in Khyber Pakhtunkhwa during 1980-81 to 2011-12. Hence area, production and productivity of wheat have increased with highly significant growth in both Haryana and India. There was appreciable increase in the productivity of wheat in India $(45.96 \mathrm{~kg} / \mathrm{ha})$ as compared to Haryana state $(30.70 \mathrm{~kg} / \mathrm{ha})$.

The coefficient of variation with respect to three components i.e. area, production and productivity of wheat crop were higher in Haryana as compared to India in all the periods and the overall period except for yield in period-II, area and production in period-V, showing thereby that wide variation has occurred in Haryana as compared to the country with respect to these parameters (Table 5). Similarly, instability indices were also higher in Haryana as compared to the country in all the sub-periods and overall period except in production in period II and area in period-V.

In Haryana, highest coefficient of variation in area under wheat crop was 16.76 percent in period-I followed by 10.05 percent during Period-II while least variation has occurred in its area i.e. 2.00 percent during Period-V. There was decreasing trend in the coefficient of variation in area as we move from Period-I through Period-V both in Haryana and all India level. Similar trends were observed for coefficient of variation and stability indices in production and yield of wheat in Haryana as well as India.

\section{Conclusions}

The study reveals positive trends in area, production and yield of wheat for both Haryana and India. The contributions of area and yield in the production of wheat crop were comparable for both Haryana and India. Similar results were obtained on triennium bases. All the three aspects (i.e. area, production and yield) have shown positive growth rates in Haryana while in case of India, positive growth rates were observed for both area and production except in Period- IV from 1996-97 to 2005-06. For the entire period under study the trend of area under wheat crop revealed a highly significant growth of 2.25 percent and for its production and productivity it was 4.77 and 2.46 percent respectively in Haryana. For India the trend coefficient for wheat crop have Shown 
Table 5 Coefficient of Variation and Instability Index of Wheat Crop in Haryana and India

\begin{tabular}{|c|c|c|c|c|c|c|c|}
\hline \multirow[b]{2}{*}{ Period } & \multirow[b]{2}{*}{ Variable } & \multicolumn{3}{|c|}{ Haryana } & \multicolumn{3}{|c|}{ India } \\
\hline & & $\mathrm{R}^{2}(\%)$ & $\begin{array}{l}\text { Coefficient of } \\
\text { Variation }(\%)\end{array}$ & $\begin{array}{l}\text { Instability } \\
\text { Index }\end{array}$ & $\mathrm{R}^{2}(\%)$ & $\begin{array}{l}\text { Coefficient of } \\
\text { Variation (\%) }\end{array}$ & $\begin{array}{c}\text { Instability } \\
\text { Index }\end{array}$ \\
\hline \multirow{3}{*}{ I } & Area & 76.69 & 16.76 & 8.09 & 77.19 & 13.29 & 6.35 \\
\hline & Production & 51.02 & 24.09 & 16.90 & 71.34 & 23.74 & 12.70 \\
\hline & Yield & 8.07 & 12.93 & 12.40 & 60.14 & 12.63 & 7.97 \\
\hline \multirow{3}{*}{ II } & Area & 86.54 & 10.05 & 3.69 & 64.07 & 4.86 & 2.91 \\
\hline & Production & 95.19 & 21.20 & 4.65 & 91.55 & 16.69 & 4.85 \\
\hline & Yield & 86.96 & 12.53 & 4.52 & 91.98 & 12.82 & 3.63 \\
\hline \multirow{3}{*}{ III } & Area & 78.93 & 5.04 & 2.31 & 71.89 & 3.85 & 2.04 \\
\hline & Production & 85.16 & 14.02 & 5.40 & 88.05 & 12.34 & 4.27 \\
\hline & Yield & 77.08 & 9.93 & 4.75 & 85.61 & 9.05 & 3.43 \\
\hline \multirow{3}{*}{ IV } & Area & 56.86 & 5.25 & 3.45 & 3.74 & 2.74 & 2.69 \\
\hline & Production & 30.08 & 8.16 & 6.82 & 0.19 & 4.47 & 4.47 \\
\hline & Yield & 2.11 & 3.84 & 3.80 & 0.97 & 3.38 & 3.36 \\
\hline \multirow{3}{*}{ V } & Area & 69.35 & 2.00 & 1.11 & 85.19 & 3.19 & 1.23 \\
\hline & Production & 58.8 & 8.31 & 5.33 & 91.55 & 8.83 & 2.57 \\
\hline & Yield & 45.74 & 6.87 & 5.06 & 87.57 & 5.79 & 2.04 \\
\hline \multirow{3}{*}{ Overall } & Area & 91.10 & 28.01 & 8.45 & 83.53 & 16.95 & 6.88 \\
\hline & Production & 93.74 & 53.32 & 13.5 & 91.87 & 43.38 & 12.4 \\
\hline & Yield & 91.96 & 31.46 & 9.02 & 93.18 & 30.53 & 7.97 \\
\hline
\end{tabular}

positive growth rates of $1.25,3.68$ and 2.40 percent respectively during this period. Hence area, production and productivity of wheat have increased with highly significant growth in both Haryana and India. Trend of yield in India was similar to that of Haryana. Similar results were observed for coefficient of variation and stability indices in production and yield of wheat in Haryana as well as India.

\section{Conflict of interests}

There is no conflict of interest.

\section{References}

Abid S, Nisar AS, Hassan A, Farooq A (2014) Growth and trend in area, production and yield of major crops of Khyber Pakhtunkhwa, Pakistan. Asian Journal of Agriculture and Rural Development 4: 149-155.
Abraham TP, Raheja SK (1967) An Analysis of Growth of Production of Rice and Wheat Crops in India. Indian Journal of Agricultural Economics 22: 2-11.

Ali MA, Singh AK (1995) Growth and Fluctuation in Area, Production and Productivity of Wheat in Chattisgarh Region of Madhya Pradesh. Indian Journal of Agricultural Economics 50: 609-614.

Bastine CL, Palanisami KP (1994) an analysis of growth trends in principal crops in Kerala. Agricultural Situation in India, 48: 885-891.

Bhatnagar S, Saxena KK (2000) an Estimate of Area and Production of Wheat in Haryana. Agricultural Situation in India 56: 665-667.

Bhatnagar S, Nandal, DS (1994) Growth of Wheat in Haryana. Agricultural Situation in India 49: 575-578. 
Ganjeer PK, Kaushik D, Lakhera ML (2017) A Review on Trend in Area, Production and Productivity of Wheat Crop in different Districts of Northern Hills of Chhattisgarh State. Bulletin of Environment, Pharmacology and Life Sciences 6: 302-304.

Gautam AK, Sisodia BVS (2018) Analysis of trends and growth rate of wheat crop and forecast of its production in Uttar Pradesh. Journal of Pharmacognosy and Phytochemistry 7: 3306-3310.

Gupta BS, Saraswat PK (1997) Growth of rapeseed and mustard in Western Rajasthan. Agriculture Situation in India 54: 261-263.

Kumar V, Patle GT, Singh DR, Chand R (2017) Trend of Area, Production and Productivity of Major Cereal Crops in Context of Food Security: Sikkim, India. International Journal of Engineering Technology Science and Research 4: 2394-3386.

Laitonjam N, Singh R, Yumnam A, Kalai K, Meena NK (2018) Pulses Production in India: Decomposition and trend analysis. Plant Archives 18: 435-438.

Netam OM, Sahu LK (2017) Decade trend analysis of area, production and productivity of paddy in Bastar region of Chhattisgarh state. Plant Archives 17: 158-160.

Siju T, Kombairaju S (2001) Rice production in Tamil Nadu: A trend and decomposition analysis. Agricultural Situation India 58: 143-145.

Singh M, Supriya K (2017) Growth Rate and Trend Analysis of Wheat Crop in Uttar Pradesh, India. International Journal of Current Microbiology and Applied Sciences 6: 2295-2301.

Singh, RKP, Ranjan KP (1998). Growth and instability in production of principal food grains cops: A case of backward economy. Bangladesh Journal of Agricultural Economics 21: 1-20.

Statistical Abstract of Haryana, Department of Economics and Statistical Analysis, Haryana. Available on http://esaharyana.gov.in/en-us/State-Statistical-Abstract-ofHaryana access on $12^{\text {th }}$ January, 2019.

Statistical Abstract of India, Department of Economics and Statistical Analysis, India. Available on https://www.indiaagristat.com/agriculture-data/2/agriculturalarea-land-use/152/stats.aspx access on 12th January, 2019. 